\title{
Heterospecific sociality of birds on beaches from southeastern Brazil
}

\author{
César Cestari
}

Departamento de Zoologia, Instituto de Biociências, Universidade Estadual Paulista Júlio de Mesquita Filho.
Avenida 24-A 1515, Caixa Postal 199, 13506-900 Rio Claro, São Paulo, Brasil. E-mail: cesar_cestari@yahoo.com.br

\begin{abstract}
Studies on the sociality of heterospecific assemblages of birds have promoted a greater understanding of the types of interactions and survivorship between coexisting species. This study verified the group compositions in bird assemblages and analyzed the sociality of migratory and resident species on sandy beaches of southeastern Brazil. A transect was established on the median portion of beaches and all the groups of bird species (monospecific, heterospecific) and solitary individuals were registered four days per month from November 2006 to April 2007. The sociality of each species was calculated by its frequency in heterospecific groups, its proportional number of contacts with other species in heterospecific groups, and the number of species that it associated with. Semipalmated Sandpiper Calidris pusilla (Linnaeus, 1766) and Semipalmated Plover Charadrius semipalmatus Bonaparte, 1825 (both migratory) had the highest degree of sociality and did not show a preference to associate with either residents or migratory species. Sanderling Calidris alba (Pallas, 1764) (migratory) occupied the third position in the sociality rank and associated with migratory species frequently. Southern Caracara Carara plancus (Miller, 1777) and Black Vulture Coragyps atratus (Beschstein, 1793) (both resident) were uniquely found among heterospecific groups with necrophagous and resident species. Kelp Gull Larus dominicanus Lichtenstein, 1823 (resident) associated more frequently with resident species. The sociality in assemblages of birds may promote advantages such as an increased collective awareness in dangerous situations and indication of sites with abundant food sources.
\end{abstract}

KEY WORDS. Association; competition; heterospecific groups; Nearctic migrants; shorebirds.

Sociality in animals is related with the response of individuals to various features of the environment, including other individuals of the same or different species (Brown \& Orians 1970). For birds, open habitats like beaches enhance the facility to detect predators at far distances and have a continuous food supply from the ocean. These features may favor the presence of large groups with variable composition of birds (RECHER \& ReCHer 1969, TeRborgh 1990).

Assemblages of birds may diminish the risk of predation due to a collective cautious action of some individuals that favor the group (Cresswell 1994, Elgar 1989, Mori et al. 2001), and reduce the probability that an individual may be captured by a predator (PIERSMA 1996). Furthermore, certain species of birds attract other individuals in group feeding situations acting as indicators of high quality places to forage (SMITH 1995). In this way, more sociable species may be less vulnerable to predation and experience increased food input encounters due to the tendency to assemble in heterospecific groups. Contrary to these benefits, some authors argue that species may compete aggressively for space in groups where food is abundant, but all these circumstances are also dependent upon the sociality of species, compositions and flocks sizes, different feeding methods of species, and changes in feeding spaces and distribution of food within tidal cycles (Recher \& Recher 1969, Burger et al. 1977, 2007).
According to BURGER et al. (1977), migratory shorebirds may spend most of the year with heterospecific groups and certain species tend to associate in groups consistently. Hence, supplementary natural history information may be of paramount importance to understand species association and interactions of coexisting birds, including temporary ones involving migratory species that come from Nearctic regions every year in non-breeding period and spend several months with resident birds in tropical coast areas (SICK 1997). This study aims: (1) to reveals the group compositions of migratory and resident birds (monospecific, heterospecific and solitarily) and (2) to analyze the sociality of these species along a coastal region of southeastern Brazil.

\section{MATERIAL AND METHODS}

The study was conducted on a $9 \mathrm{~km}$ section of continual sandy beaches composed of fine granulation sediments in the municipalities of Itanhaém and Peruíbe, along the south coast of state of São Paulo ( $\left.24^{\circ} 13^{\prime}-24^{\circ} 16^{\prime} \mathrm{S}, 46^{\circ} 51^{\prime}-46^{\circ} 55^{\prime} \mathrm{W}\right)$. Climate of the region is subtropical and humid. Mean annual rainfall is $2278 \mathrm{~mm}$ with the rainy season occurring from October to April, and the dry season from May to September. Mean annual temperature is $21.4^{\circ} \mathrm{C}$, with maximum temperatures averaging $25.8^{\circ} \mathrm{C}$ and minimum temperatures averaging $19.0^{\circ} \mathrm{C}$ (TARIFA 2004). The northern portion of the study area is an urban landscape with 
residential areas, whereas the southern portion is bordered by the native restinga vegetation with shrubs, cacti and terrestrial bromeliads, without intense human occupancy and activities due the absence of residential areas. The relief of the beaches was smooth with low declivity (of $4^{\circ}$ to $6^{\circ}$ ) and moist on most part of the tide line $(87 \pm 9 \mathrm{~m})$. Only a small portion out from the reach of the tide line (nearly $10 \mathrm{~m}$ ) was soft and drier.

A transect crossing the middle of the beaches was established and all the groups of bird species (monospecific and heterospecific) and solitary individuals were registered in the morning (8:30-10:30 h) for four days a month from November 2006 to April 2007, totaling 48 hours of observations. Each solitary individual, monospecific or heterospecific group registered was treated as a single contact. The individuals found grouped within an estimated distance less than $5 \mathrm{~m}$ to each other on the ground were considered to be a group. This maximum distance of individuals was adopted due to the typical unidirectional movements and cohesion of flocking species when they were perturbed by people or dogs in previous field observations (CESTARI 2008). Groups of flying birds were differentiated when individuals moved in the same direction within a maximum estimated distance of $10 \mathrm{~m}$ to each other.

The general term "group" (instead "flock") was employed for all assemblages of birds because some species (i.e. vultures, gulls and falcons) frequently exhibited non-unidirectional movement and lacked cohesion of individuals (HeppNer 1974).

To discriminate the sociality (S) of species that participated of heterospecific groups, three variables were considered: its frequency in heterospecific groups (Fr), its proportional number of contacts with another species in heterospecific groups $(\mathrm{P})$ and the number of species that it associated with (s). Their relationship is shown in the following formula: $\mathrm{S}=$ Fr.P.s.

The species frequency (Fr) was obtained by dividing its number of contacts in heterospecific groups (n) and its total sum of contacts in heterospecific groups, monospecific groups and solitary individuals (N). The Fr's were multiplied by 100 to obtain percentage values $-\mathrm{Fr}=(\mathrm{n} / \mathrm{N}) .100$.

The species proportional number of contacts with other species in heterospecific groups (P) was obtained by dividing its number of contacts with another species in heterospecific groups $\left(\mathrm{p}_{1}\right)$, and the total number of contacts of all species in heterospecific groups $\left(\mathrm{p}_{\mathrm{t}}\right)$. The P's were multiplied by 100 to obtain the percentage values $-\mathrm{P}=\left(\mathrm{p}_{1} / \mathrm{p}_{\mathrm{t}}\right) \cdot 100$.

The sociality ( $\mathrm{S}$ ) favors the qualitative aspect of interspecific interactions being directly proportional with the species frequency in heterospecific groups (Fr), the proportional number of contacts in heterospecific groups $(\mathrm{P})$, and the number of associated species (s). A plentiful species in terms of abundance may not be necessarily more social if does not fit these variables. For example, following the sociality formula ( $\mathrm{S}=$ Fr.P.s), species $A$ with 2,000 individuals registered in 10 heterospecific groups, thirty monospecific groups and two solitaries $[\mathrm{Fr}=(10 / 42) .100]$, with $\mathrm{p}_{1}=20$ in a $\mathrm{p}_{\mathrm{t}}=80[\mathrm{P}=(20 / 80) .100]$ and associated with three species $(s=3)$ is nearly twenty-two times less social $(S=1.785)$ than species B with 200 individuals registered in 30 heterospecific groups, two monospecific groups and one solitary $[\mathrm{Fr}=(30 / 33)$. $100]$, with $\mathrm{p}_{1}=50$ in a $\mathrm{p}_{\mathrm{t}}=80[\mathrm{P}=(50 / 80) .100]$ and associated with seven species $(s=7)$, totaling $S=39.769$.

Chi-square test $\left(\chi^{2}\right)$ with Yates correction was applied to verify if $\mathrm{p}_{1}$ with migratory and resident species for each species were significant. The significance $\alpha \pm=5 \%$ was established for all the analyses and only species with 10 or more contacts were analyzed in this study. Occurrence status (resident or migratory) of the bird species follows the list of Brazilian Ornithological Committee (СвRо 2008).

\section{RESULTS}

Fourteen resident species Magnificent Frigatebird Fregata magnificens Mathews, 1914, Fregatidae, Great Egret Ardea alba Linnaeus, 1758, Ardeidae, Snowy Egret Egretta thula (Molina, 1782), Ardeidae, Turkey Vulture Cathartes aura (Linnaeus, 1758), Cathartidae, Black Vulture Coragyps atratus (Beschstein, 1793), Cathartidae, Southern Caracara Carara plancus (Miller, 1777), Falconidae, Southern Lapwing Vanellus chilensis (Molina, 1782), Charadriidae, Collared Plover Charadrius collaris Vieillot, 1818, Chadriidae, American Oystercatcher Haematopus palliatus Temminck, 1820, Haematopodidae, Wattled Jacana Jacana jacana (Linnaeus, 1766), Jacanidae, Kelp Gull Larus dominicanus Lichtenstein, 1823, Laridae, Royal Tern Thalasseus maximus (Buddaert, 1783), Sternidae, Black Skimmer Rhynchops niger Linnaeus, 1758, Rhyncopidae, Rock Dove Columba livia Gmelin, 1789, Columbidae and six non-breeding Nearctic migratory species American Golden Plover Pluvialis dominica (Statius Muller, 1776), Charadriidae, Semipalmated Plover Charadrius semipalmatus Bonaparte, 1825, Charadriidae, Ruddy Turnstone Arenaria interpres (Linnaeus, 1758), Scolopacidae, Red Knot Calidris canutus (Linnaeus, 1758), Scolopacidae, Sanderling Calidris alba (Pallas, 1764), Scolopacidae, Semipalmated Sandpiper Calidris pusilla (Linnaeus, 1766), Scolopacidae were registered. A total of 3,868 individuals of these two statuses formed 806 contacts of monospecific groups and heterospecific groups, but 250 individuals were solitary. A. alba (one contact), C. aura, C. collaris and $R$. niger (two contacts each species), C. canutus and J. jacana (three contacts each species), A. interpres and F. magnificens (eight contacts each species) were excluded from the analyses due to a low number of contacts. The rest of the species with more than 10 contacts were registered participating in monospecific groups, heterospecific groups and solitarily (Tab. I).

Considering the heterospecific groups, C. semipalmatus had the highest number of contacts with 13 species $\left(\mathrm{P}=31.6 \%, \mathrm{p}_{1}=\right.$ 101). C. pusilla $\left(\mathrm{P}=17.5 \%, \mathrm{p}_{1}=56\right)$ and C. alba $\left(\mathrm{P}=10.9 \%, \mathrm{p}_{1}=\right.$ 35 ) had the second and third highest number of contacts with other species (Tab. II). Including the total frequency of contacts (Fr) in heterospecific groups and the total number of associated species (s) in the analyses, C. pusilla, C. semipalmatus and C. alba had the highest degree of sociality, respectively (Fig. 1). 


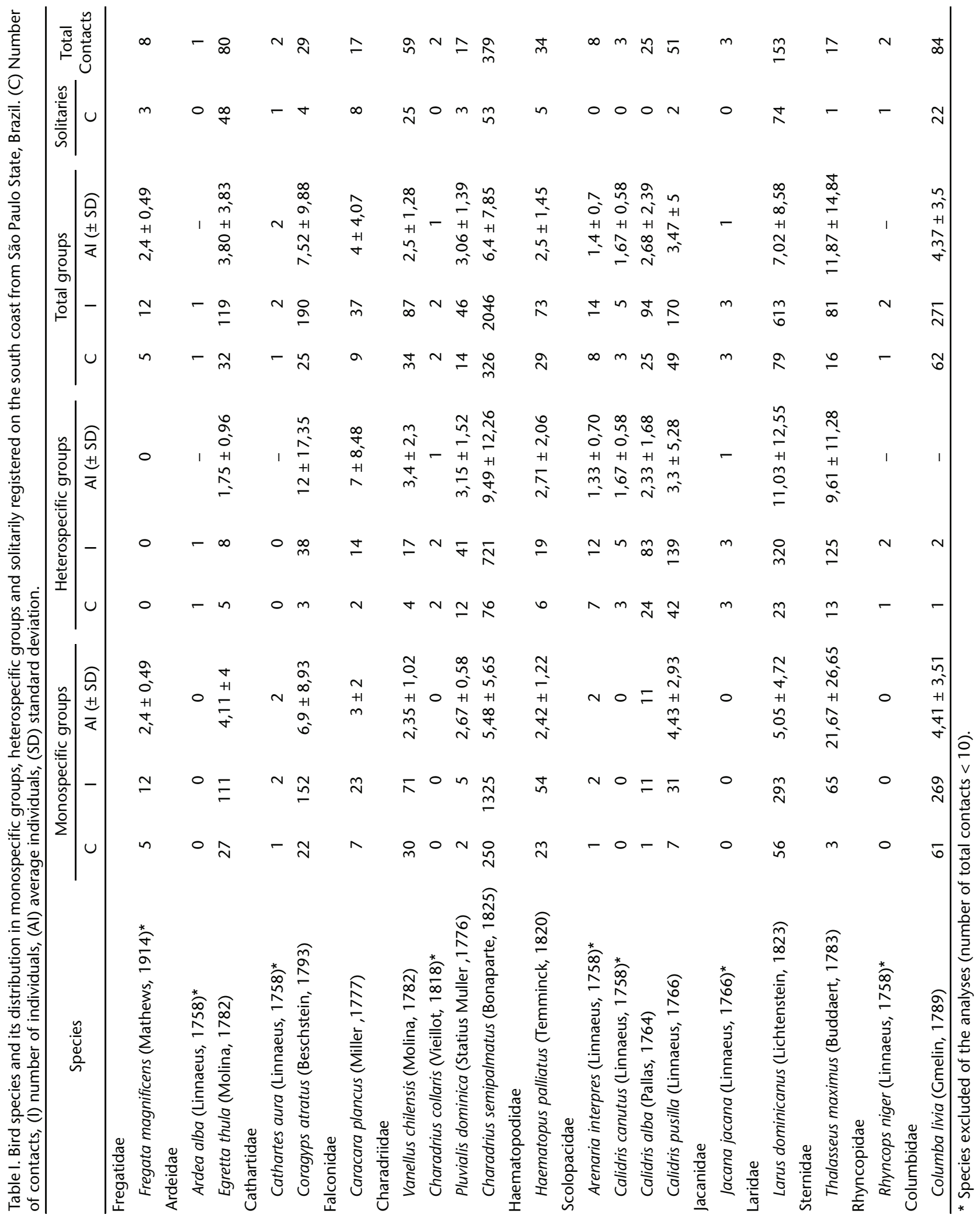




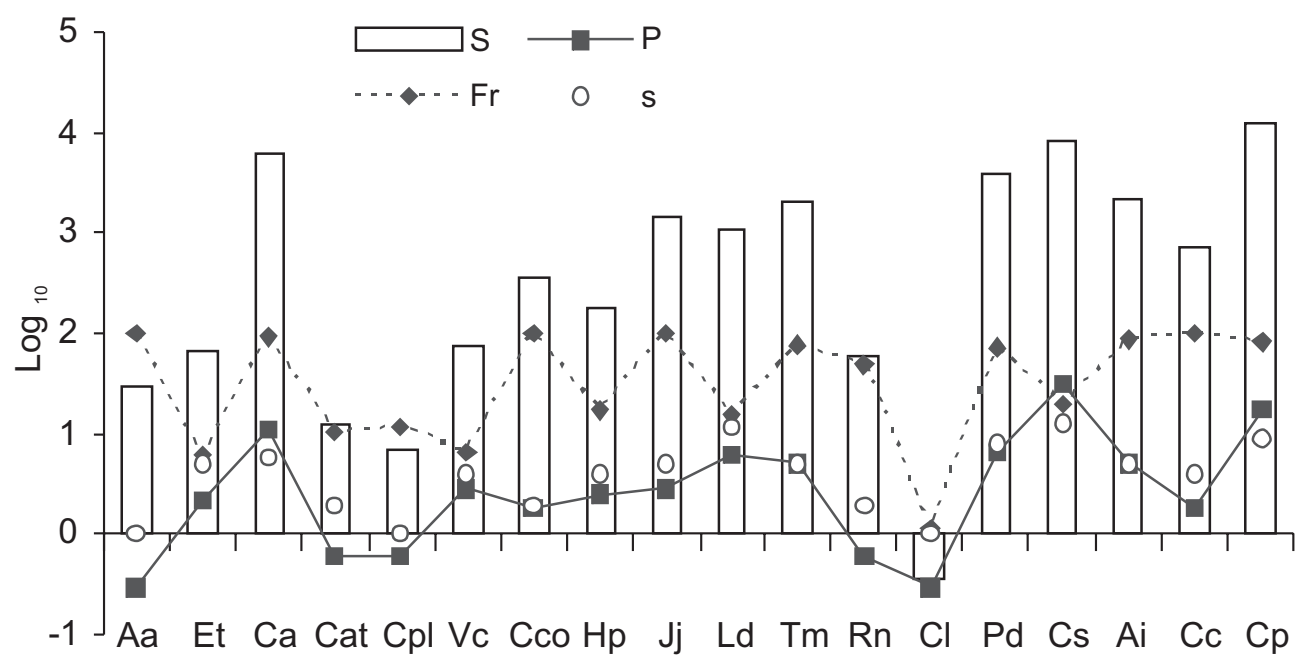

Figure 1. Sociality (S), frequency in heterospecific groups ( Fr), proportional number of contacts with another species in heterospecific groups $(P)$ and the number of species that each registered species interacted (s) on the south coast from São Paulo State, Brazil. The $Y$ axis values were converted in logarithm scale $\left(\log { }_{10}\right)$. Letters in the $X$ axis means scientific names that are described on the legend of table II.

Table II. Number of contacts between species that participated of heterospecific groups in southeastern coast, Brazil. (p1) number of contacts with another species in heterospecific groups; (s) total number of interacted species; (Cs) C. semipalmatus, (Cp) C. pusilla, (Ca) C. alba, (Tm) T. maximus, (Ai) A. interpres, (Pd) P. dominica, (Ld) L. dominicanus, (Vc) V. chilensis, (Jj) J. jacana, (Cc) C. canutus, (Et) E. thula, (Hp) H. palliatus, (Cco) C. collaris, (Cl) C. livia, (Cpl) C. plancus, (Cat) C. atratus, (Aa) A. alba, (Rn) R. niger.

\begin{tabular}{|c|c|c|c|c|c|c|c|c|c|c|c|c|c|c|c|c|c|c|}
\hline & Cs & $C p$ & $\mathrm{Ca}$ & $\mathrm{Tm}$ & $\mathrm{Ai}$ & $\mathrm{Pd}$ & Ld & Vc & Jj & Cc & Et & $\mathrm{Hp}$ & Cco & $\mathrm{Cl}$ & Cpl & Cat & $\mathrm{Aa}$ & $\mathrm{Rn}$ \\
\hline Cs & $x$ & 35 & 22 & 12 & 8 & 7 & 3 & 3 & 2 & 2 & 2 & 2 & 2 & 1 & 0 & 0 & 0 & 0 \\
\hline$C p$ & 35 & $x$ & 6 & 0 & 1 & 4 & 1 & 3 & 3 & 1 & 0 & 0 & 2 & 0 & 0 & 0 & 0 & 0 \\
\hline $\mathrm{Ca}$ & 22 & 6 & $x$ & 0 & 3 & 2 & 1 & 0 & 0 & 1 & 0 & 0 & 0 & 0 & 0 & 0 & 0 & 0 \\
\hline $\mathrm{Tm}$ & 12 & 0 & 0 & $x$ & 0 & 1 & 1 & 0 & 0 & 0 & 1 & 2 & 0 & 0 & 0 & 0 & 0 & 1 \\
\hline $\mathrm{Ai}$ & 8 & 1 & 3 & 0 & $x$ & 2 & 2 & 0 & 0 & 0 & 0 & 0 & 0 & 0 & 0 & 0 & 0 & 0 \\
\hline $\mathrm{Pd}$ & 7 & 4 & 2 & 1 & 2 & $x$ & 2 & 0 & 0 & 2 & 0 & 2 & 0 & 0 & 0 & 0 & 0 & 0 \\
\hline Ld & 3 & 1 & 1 & 1 & 2 & 2 & $x$ & 1 & 1 & 0 & 2 & 4 & 0 & 0 & 0 & 1 & 0 & 1 \\
\hline Vc & 3 & 3 & 0 & 0 & 0 & 0 & 1 & $x$ & 2 & 0 & 0 & 0 & 0 & 0 & 0 & 0 & 0 & 0 \\
\hline Jj & 2 & 3 & 0 & 0 & 0 & 0 & 1 & 2 & $x$ & 0 & 1 & 0 & 0 & 0 & 0 & 0 & 0 & 0 \\
\hline Cc & 2 & 1 & 1 & 0 & 0 & 2 & 0 & 0 & 0 & $x$ & 0 & 0 & 0 & 0 & 0 & 0 & 0 & 0 \\
\hline Et & 2 & 0 & 0 & 1 & 0 & 0 & 2 & 0 & 1 & 0 & $x$ & 0 & 0 & 0 & 0 & 0 & 1 & 0 \\
\hline $\mathrm{Hp}$ & 2 & 0 & 0 & 2 & 0 & 2 & 4 & 0 & 0 & 0 & 0 & $x$ & 0 & 0 & 0 & 0 & 0 & 0 \\
\hline Cco & 2 & 2 & 0 & 0 & 0 & 0 & 0 & 0 & 0 & 0 & 0 & 0 & $x$ & 0 & 0 & 0 & 0 & 0 \\
\hline $\mathrm{Cl}$ & 1 & 0 & 0 & 0 & 0 & 0 & 0 & 0 & 0 & 0 & 0 & 0 & 0 & $x$ & 0 & 0 & 0 & 0 \\
\hline Cpl & 0 & 0 & 0 & 0 & 0 & 0 & 0 & 0 & 0 & 0 & 0 & 0 & 0 & 0 & $x$ & 2 & 0 & 0 \\
\hline Cat & 0 & 0 & 0 & 0 & 0 & 0 & 1 & 0 & 0 & 0 & 0 & 0 & 0 & 0 & 2 & $x$ & 0 & 0 \\
\hline $\mathrm{Aa}$ & 0 & 0 & 0 & 0 & 0 & 0 & 0 & 0 & 0 & 0 & 1 & 0 & 0 & 0 & 0 & 0 & $x$ & 0 \\
\hline $\mathrm{Rn}$ & 0 & 0 & 0 & 1 & 0 & 0 & 1 & 0 & 0 & 0 & 0 & 0 & 0 & 0 & 0 & 0 & 0 & $x$ \\
\hline p1 & 101 & 56 & 35 & 17 & 16 & 22 & 20 & 9 & 9 & 6 & 7 & 8 & 4 & 1 & 2 & 3 & 1 & 2 \\
\hline$s$ & 13 & 9 & 6 & 5 & 5 & 8 & 12 & 4 & 5 & 4 & 5 & 4 & 2 & 1 & 1 & 2 & 1 & 2 \\
\hline
\end{tabular}


No species with more than 10 contacts associated with heterospecific groups formed exclusively by migration. Only C. alba (migratory) associated frequently with migratory species $\left(\Sigma \chi_{(1)}^{2}=9.19, \mathrm{p}=0.024, \mathrm{n}=34\right)$, mainly with $C$. semipalmatus $\left(\mathrm{p}_{1}=22\right.$, nearly $63 \%$ of total contacts, Tab. II).

Caracara plancus and C. atratus constituted heterospecific groups formed uniquely by resident species and, L. dominicanus (resident) interacted more with resident species $\left(\Sigma \chi_{(1)}^{2}=8.34\right.$, $\mathrm{p}=0.039, \mathrm{n}=11$, Tab. II). Columba livia, an exotic and resident species in Brazil, associated only in one group with $C$. semipalmatus, a migratory species (Tab. II).

\section{DISCUSSION}

Three migratory species C. pusilla, C. semipalmatus and C. alba displayed similar frequency in heterospecific groups (Fr), number of contacts with another species (P) and number of species interacted (s) that reflected their highest sociality. Additionally, C. pusilla and C. semipalmatus participated of heterospecific groups with no significant preference of association with either residents or migratory species. In route, migratory birds face a myriad of ecological and physiological challenges (SKAGEN 2006) and as a rule, the social plasticity with other species may be important to explore among habitats with a high richness of birds (migratory or not) during their permanence in wintering areas. Despite the general occurrence of ecological division of coastal bird species by the feeding niches available during different times of the year (Vooren \& CHIARADIA 1990), interspecific competition for space and food may exist (Pravosudov et al. 1994, Burger et al. 2007). However, advantages such as the decrease in predation risk (ELGAR 1989), reduction of the probability that an individual be captured by a predator (PIERSMA 1996), and the indication of suitable habitats where the birds are concentrated (SMITH 1995) would compensate for these negative challenges.

Interspecific agonistic behaviors are less frequent than intraspecific encounters due to probable differences in morphological aspects and ecological tactics molded by evolutionary processes in distinct species (RECHER \& RECHER 1969). Competitions for food between distant related species are rarely registered (AtKINs 1980, BURGER 2007) and the majority of studies on avian resource sharing have assumed that competition will be most severe between closely related forms (RECHER \& RECHER 1969). According to MatThysen (1994), the relative number of individuals per species decreases in a heterospecific group when the number of species per group increases. In this way aggregation of sociable species increasing the richness in heterospecific groups may be important collectively in reducing intraspecific competitions due to the common indifference to compete between species in groups (RECHER \& RECHER 1969). Furthermore, the more sociable species may benefit when they are temporarily refueling with other species and cannot flee to suitable areas, even in rare situations of highly competitive places, in low quality staging sites or bad physiological conditions (GILL et al. 2001).
Despite its high sociality, C. alba showed preference to join with migratory species. Sick (1997) mentioned the frequent association of C. alba in heterospecific groups of Nearctic birds on the peak period of migration. Nearctic birds breed in North America during the summer moving to South America in the winter to feed and rest (Sick 1997, LarrazÁBAL et al. 2002). The association of Nearctic migratory birds is related to the same stopover sites used along the route of Brazilian Atlantic coast. According to Sick (1997), Nearctic birds arrive in Brazil mainly along the Atlantic coast and the Amazon basin (north and northeastern regions), and crossing the country at the Patagonian southern extreme point in Argentina. LyRA-Neves et al. (2004), showed the use of Atlantic route by C. alba in a observation study carried out at Coroa do Avião (northeast coast of Brazil) to recover codes established in the Pan-American Shorebirds Program. They used three places on the Atlantic route where individuals were ringed: Coroa do Avião (northeastern Brazil), Lagoa do Peixe (southern Brazil) and Maranhão (northern Brazil). Proving it, some authors registered the majority of Nearctic species of this study (C. semipalmatus, C. alba, C. pusilla, C. canutus, $A$. interpres and $P$. dominica) along the Brazilian coast in north (Rodrigues 2000), northeast (Telino-JunIOR et al. 2003, CABral et al. 2006), southeastern (Olmos \& Silva 2001, Barbieri \& MENDONÇA 2005) and south (Vooren \& Chiaradia 1990, BRANCo et al. 2004) regions.

Among the migratory species, C. alba had a higher number of proportional contacts with C. semipalmatus. These species share intertidal areas, but they avoid competition during foraging differently. C. alba foraged more tactilely than visually by frequently probing its bill in the sand. According to Piersma (1996), this species has an array of sensory receptors in the bill tips that allow it to detect the vibrations of small polychaetes at distances of $2 \mathrm{~cm}$ from the bill tip. C. semipalmatus fed by sight and waited for prey on the surface of the ground, sometimes trembling the feet to reveal a prey.

The resident C. plancus and C. atratus were observed feeding on dead animals (mainly fish) in heterospecific groups (including L. dominicanus, ) on the beaches of this region. Interactions between scavenger species are common when dead animals are encountered. In this context, considering the overlap of diets that include carcasses, no other function beyond competition for food is attributed for grouping of these resident species. Probably the assemblages of individuals around the food attract more individuals (SMITH 1995) and hierarchy dominance based mainly on body size between these scavenger species may exist to mitigate competition (WAllace \& TeMple 1987).

Larus dominicanus (resident) had a significant number of contacts while resting in heterospecific groups with residents (T. maximus, R. niger, V. chilensis, E. thula, and H. palliatus) along the tide line or feeding upon carcasses (registered once in association with $C$. atratus) on upper beach. Its presence during the year on the southeast Brazilian coast (BARBIERI \& MENDONÇA 2008) probably influenced the customary association with other 
resident species. Vooren \& Chiaradia (1990) cited frequent association between L. dominicanus and T. maximus in groups with more than 50 individuals resting on a beach in south coast of Brazil. It's feasible that $L$. dominicanus associates in heterospecific groups as a defense strategy when resting (BARBIERI $\&$ PINNA 2007). Some species members that associated in groups, such as T. maximus, $R$. niger and $H$. palliatus, are lesser in body weight and have a higher capacity to escape in dangerous situations than L. dominicanus providing an early warning system. Observations in this study revealed that these features may offer reasons why $L$. dominicanus was observed fleeing first in circumstances of humans and domestic dog approximation.

SICK (1997) cited the necrophagous behavior of $L$. dominicanus feeding on animal carcasses and garbage along the beach, as observed in this study. According to BARBIERI \& Mendonça (2008), this species may be favored due to its opportunistic behavior in feeding upon waste from shrimp fishing and other human actions that increase dead marine organisms on the beaches of southeastern coast region. In this study, $L$. dominicanus associated with $C$. atratus only to feed on a big dead fish, keeping far from the group when the number of vultures exceeded four individuals.

Columba livia (resident) was observed once with $C$. semipalmatus (migratory) in a feeding situation. This species was introduced as domestic bird in Brazil in the 15th century and quickly adapted to anthropogenic places (SICK 1997). Normally this opportunistic dove is encountered in monospecific groups feeding on the remains of human food (bread, peanuts and appetizers) discarded on the beach. Its unique contact of association with C. semipalmatus was probably due to a high concentration of food section on the beach. C. semipalmatus forages for polychaete worms, small gastropods, crustaceans and insects (Wiersma 2000) and its diet differs broadly of $C$. livia eliminating any possible competition.

Studies on sociality of coastal species are scarce, and this study provides a background to measure it in further analyses, and to better understand the associations and interactions between coexisting birds. Previously available information indicated less inter-specific agonistic behavior than in intra-specific contacts in birds (Recher \& Recher 1969). Despite the differences in morphological and ecological aspects, when competition emerges more sociable species may have survivorship advantages over less sociable individuals.

\section{ACKNOWLEDGEMENTS}

I am especially indebted to Glen Mori for gently providing the English revision and making important suggestions to the manuscript.

\section{LITERATURE CITED}

Atkins, N. 1980. Possible competition between Seaside Cinclodes (Cinclodes nigrofumosus) and Ruddy Turnstones (Arenaria interpres). Condor 82 (1): 107-108.
Barbieri, E. \& J.T. Mendonça. 2005. Distribution and abundance of Charadriidae at Ilha Comprida, São Paulo State, Brazil. Journal of Coastal Research 21 (2): 1-10.

BARbieri, E. \& F.V. PINNA. 2007. Distribuição do Trinta-réis-real (Thalasseus maximus) durante 2005 no estuário de CananéiaIguape-Ilha Comprida. Ornitologia Neotropical 18 (1): 99110.

Barbieri, E. \& J.T. Mendonça. 2008. Seasonal abundance and distribution of Larids at Ilha Comprida. Journal of Coastal Research 24 (1): 70-78.

Branco, J.O.; I.F. Machado \& M.S. Bovendorp. 2004. Avifauna associada a ambientes de influência marítima no litoral de Santa Catarina, Brasil. Revista Brasileira de Zoologia 21 (3): 459-466.

Brown, J.L. \& G.H. Orians. 1970. Spacing pattern in mobile animals. P. 239-262. In: Johnson, R. F. (Ed.). Annual Review of Ecology and Systematics 1 (1): 239-262.

Burger, J.; A. Marshall; D. Howe; H. Caldwell \& J. Chase. 1977. Effects of tide cycles on habitat selections and habitat partitioning by migranting shorebirds. Auk 94 (4): 743-758.

Burger, J.; S.A. Carlucci; C.W. Jeitner \& L. Niles. 2007. Habitat choice, disturbance, and management of foraging shorebirds and gulls at a migratory stopover. Journal of Coastal Research 23 (5): 1159-1166.

Cabral, S.A.S; S.M. Azevedo-Júnior \& M.E. LarrazÁbal. 2006. Abundância sazonal de aves migratórias na Área de Proteção Integral de Piaçabuçu, Alagoas, Brasil. Revista Brasileira de Zoologia 23 (3): 865-869.

Cвro. 2008. Lista das aves do Brasil. Comitê Brasileiro de Registros Ornitológicos Disponible in the World Wide Web: http:/ /www.cbro.org.br/CBRO/listabr.htm. Acessed in 05/10/2008.

Cestari, C. 2008. O uso de praias arenosas com diferentes concentrações humanas por espécies de aves de aves limícolas (Charadriidae e Scolopacidae) neárticas no sudeste do Brasil. Available online at: http://www.biotaneotropica.org.br/ v8n4/pt/abstract?article+bn01308042008 [Acessed in 20/ XII/2008].

Cresswell, M.A. 1994. Flocking as an effective anti-predation strategy in redshanks, Tringa tetanus. Animal Behavior 47 (2): 433-442.

ElGAR, M.A. 1989. Predator vigilance and group size in mammals and birds: a critical review of the empirical evidence. Biological Review 64 (1): 13-23.

Gill, J.A.; K. Norris \& W.J. Sutherland. 2001. Why behavioral responses may not reflect the population consequences of human disturbance. Biological Conservation 97 (2): 265268.

Heppner, F.H. 1974. Avian flight formations. Bird-Banding 45 (2): $160-169$.

Larrazábal, M.E.; S.M. Azevedo-Júnior \& O. Pena. 2002. Monitoramento de aves limícolas na salina Diamante Branco, Galinhos, Rio Grande do Norte, Brasil. Revista Brasileira de Zoologia 19 (4): 1081-1089. 
Lyra-Neves, R.M; S.M. de Azevedo-Júnior \& W.R. Telino-Júnior. 2004. Monitoramento do maçarico-branco, Calidris alba (Pallas) (Aves, Scolopacidae), através de recuperações de anilhas coloridas, na Coroa do Avião, Igarassu, Pernambuco, Brasil. Revista Brasileira de Zoologia 21 (2): 319-324.

Matthysen, E. 1994. Interaction between mixed-species flocking and intraspecific social organization. Journal of Ornithology 135 (3): 307.

Mori, Y.; N.S. Sodhi; S. KaWAnishi \& S. Yamagishi. 2001. The effect of human disturbance and flock composition on the flight distance of waterfowl species. Journal of Ethology 19 (2):115-119.

Olmos, F. \& R.S. Silva. 2001. The avifauna of the southeastern Brazilian mangrove swamp. International Journal of Ornithology 4 (3-4): 137-207.

Pravosudov, V.V.; D.A. Cimprish \& T.C. Grubb JR. 1994. Behavioral, nutrition condition and survivorship in mixed-species foraging groups: an experimental approach. Journal of Ornithology 135 (3): 310.

Piersma, T. 1996. Family Scolopacidae, p. 444-487. In: Del Hoyo, J; A. Elliott \& J. Sargatal (Eds). Handbook of the birds of the world: Hoatzin to Auks. Barcelona, Lynx Editions, vol. 3, 810p.

Recher, H.F. \& J.A. Recher. 1969. Some aspects of the ecology of migrant shorebirds. Agression. Wilson Bulletin 81 (2): 140 154.

Rodrigues, A.A.F. 2000. Seasonal abundance of Nearctic shorebirds in the Gulf of Maranhão. Journal of Field Ornithology 71 (4): 665-675.
SICK, H. 1997. Ornitologia Brasileira. Rio de Janeiro, Nova Fronteira, 912p.

SMITH, J.P. 1995. Foraging sociability of nesting wading birds (Ciconiiformes) at lake Okeechobee, Florida. Wilson Bulletin 107 (3): 437-451.

SKAGEN, S.K. 2006. Migration stopovers and the conservation of the arctic-breeding Calidriidae sandpipers. Auk 123 (2): 313322.

TARIFA, J.R. 2004. Unidades climáticas dos maciços litorâneos da Juréia-Itatins, p. 42-50. In: O.A.V. Marques \& W. Duleba (Eds). Estação Ecológica Juréia-Itatins: ambiente físico, flora e fauna. Ribeirão Preto, Holos, 386p.

Telino-Júnior, W.R.; S.M. Azevedo-Júnior \& R.M. Lyra-Neves. 2003. Censo de aves migratórias na Coroa do Avião, Igarassu, Pernambuco, Brasil. Revista Brasileira de Zoologia 20 (3): 451-456.

Terborgh, J. 1990. Mixed flocks and polyspecific association: costs and benefits of mixed groups to birds and monkeys. American Journal of Primatology 21 (2): 87-100.

Vooren, C.M. \& A. Chiaradia. 1990. Seasonal abundance and behavior of coastal birds on Cassino beach, Brazil. Neotropical Ornithology 1 (1): 9-24.

Wallace, M.P. \& S.A. Temple. 1987. Competitive interactions within and between species in a guild of avian scavengers. Auk 104 (2): 290-295.

Wiersma, P. 1996. Family Charadriidae, p. 425-426. In: Del Hoyo, J; A. Elliott \& J. Sargatal (Eds). Handbook of the birds of the world: Hoatzin to Auks. Barcelona, Lynx Editions, vol. 3, 810p.

Submitted: 22.XII.2008; Accepted: 22.XI.2009.

Editorial responsibility: Kleber del Claro 